\title{
LEAF SURFACE SCANNING ELECTRON MICROSCOPY OF 16 MULBERRY GENOTYPES (Morus SPP.) WITH RESPECT TO THEIR FEEDING VALUE IN SILKWORM (Bombyx mori L.) REARING
}

\author{
B. K. Singhal ${ }^{*}$, M.F. Baqual' ${ }^{2}$, M.A. Khan ${ }^{2}$, B.B. Bindroo ${ }^{1}$, and A. Dhar ${ }^{1}$
}

\begin{abstract}
Mulberry (Morus spp.) is the only silkworm (Bombyx mori L.) food plant. In Indian sub tropics, S-146 is the only popular and ruling mulberry genotype for silkworm rearing. As a result, mulberry leaf availability is always the limiting factor, and therefore, sub tropics are contributing less than $1 \%$ of the country's total silk production compared with more than $60 \%$ under tropical conditions. Besides climatic conditions, this is due to a very limited number of mulberry genotypes available in this region for silkworm rearing. However, in the mean time, 15 mulberry genotypes viz. 'Tr-10', 'Chinese White', 'K-2', 'Sujanpur Local', 'BC $2-59$ ', 'S-1635', 'C-1730', 'Mandalaya', 'S-30' (Vishala), 'RFS-175', 'Anantha', 'C-2016', 'C-2017', 'S-41' and 'V-1' were also introduced in the sub tropics, but remained unexplored. In sericulture, leaf surface is also an important parameter for, both, the silkworm's acceptability of not having any feeding impediment and the mulberry improvement programs. The objective of this study was to explore the possibilities of using these 16 mulberry genotypes for their leaf surface characteristics by scanning electron microscopy and using them for sericulture. Based on leaf yield, stomatal size, stomatal number per unit of area and trichomes and idioblasts length, these genotypes were grouped into different categories. The mulberry genotype 'Mandalaya', in addition to the ruling genotype 'S-146' excelled because of their higher leaf yield and desired leaf surface characteristics. Furthermore, the genotypes 'K-2', 'S-41' and 'Sujanpur Local' are also suggested to develop high yield mulberry genotypes in the Indian sub tropics.
\end{abstract}

Key words: Morus indica, scanning electron microscopy, stomata, trichomes, idioblasts, leaf yield, sericulture.

\section{INTRODUCTION}

Mulberry (Morus spp.) is the sole food plant of silkworms (Bombyx mori L., Lepidoptera: Bombycidae) and its leaf quality has a great role in silkworm rearing, which in turn affects the overall silk production (Singhal et al., 2001; 2006). In India, sericulture is mostly practiced in tropical region which is contributing more than $60 \%$ of the total country's silk production. It is mainly due to congenial climatic conditions and many high yielding mulberry genotypes evolved time to time. These genotypes have been characterized for leaf surface parameters under tropical climatic conditions (Singhal et al., 1999) which is serving

${ }^{1}$ Regional Sericultural Research Station, Miran Sahib, Jammu-181 101, India.*Corresponding author (rbksinghal@rediffmail.com, drbksinghal@gmail.com).

${ }^{2}$ Central Sericultural Research \& Training Institute, Pampore - 192 121, Kashmir, India.

Received: 02 June 2009.

Accepted: 16 September 2009. as a useful tool for mulberry improvement programs. But, the sub-tropical India still contributes to only less than $1 \%$ of the total country's silk production due to very limited number of mulberry genotypes available for silkworm rearing. For this purpose, ' $\mathrm{S}-146$ ' is the only popular and most commonly used mulberry genotype exists so far, and as a result, there is always shortage of mulberry leaf for silkworm rearing. But, meanwhile, many more mulberry genotypes viz. 'Tr-10', 'Chinese White', 'K-2', 'Sujanpur Local', 'BC ${ }_{2}-59$ ', 'S-1635', 'C-1730', 'Mandalaya', 'S30' (Vishala), 'RFS-175', 'Anantha', 'C-2016', 'C-2017', ' $\mathrm{S}-41$ ' and ' $\mathrm{V}-1$ ' have also been introduced in this region but remained unexplored. To exploit these genotypes for sericulture in Indian sub tropics, the present study was undertaken for their leaf surface characteristics which may serve as guideline information for evolving high yielding mulberry genotypes, besides having their role in feeding behavior to the silkworms.

Southwood (1986) opined that mulberry leaf surface determines its adaptation to varying eco-climates, 
exchange of water vapor, $\mathrm{CO}_{2}$ and $\mathrm{O}_{2}$ through stomatal pores and the feeding quality to the silkworms. Susheelamma and Jolly (1986) have correlated leaf stomatal size and frequency with adaptation of mulberry in tropical India. Kesavacharyulu et al. (2004) reported that higher density of trichomes on mulberry leaf surface reduces the leaf acceptability to the silkworms, even if the leaf quality is biochemically superior. Therefore, the leaf surface trichomes have been considered as very significant for the mulberry breeders in identifying potential genotypes as an early selection process without going for actual rearing test. Peter et al. (1995) found that plant trichomes also have a role in insect resistance, since, growth and development of large bodied insects may be retarded due to feeding hindrance by the trichomes. Their high density causes mulberry foliage's unacceptability to the insects due to physical hindrance (Singh et al., 1971; Levin, 1973). Idioblasts have also been found to have a significant role in determining feeding quality of the mulberry leaf to the silkworms (Melikyan and Babyan, 1971). Mulberry leaf surface trichomes and idioblasts have been used for genotypes identification in Japan by Fujita and Uchikawa (1986), whereas Katsumata (1972) has classified mulberry trees on the basis of idioblasts. Shah and Kachroo (1975) stated that the information about trichomes may throw light on the preference for certain foliage by the silkworm. Biasiolo et al. (2004) found micro morphological features of 10 mulberry cultivars as an important tool for mulberry description.

Therefore, in Indian sub tropics, where only one genotype namely S-146 is used for silkworm rearing, there is a scope of increasing the silk production from at present of $1 \%$ to more, but, only when more number of mulberry genotypes are explored for sericulture to meet the overall leaf requirement. In this regard, the present study was undertaken to evaluate potential mulberry genotypes out of 16 genotypes introduced in Indian sub tropics for higher leaf yield and the feeding quality to the silkworms.

\section{MATERIALS AND METHODS}

The present study was carried out in 16 genotypes of mulberry (Morus indica L.): 'S-30' (Vishala), 'S-1635', 'S-146', 'Anantha', 'Mandalaya', 'C-1730', 'C-2016', 'C-2017', 'RFS-175', 'Tr-10', 'V-1', 'S-41', 'K-2', 'Chinese White', ' $\mathrm{BC}_{2}-59$ ' and 'Sujanpur Local' grown under bush type of plantation at $0.9 \times 0.9 \mathrm{~m}$ spacing in between plants and rows at experimental farm of Regional Sericultural Research Station ( $32^{\circ} 43^{\prime}$ N , $74^{\circ} 54^{\prime}$ E; 250 m.a.s.l.), Miran Sahib, Jammu, India. The type of soil was sandy clay loam, pH 7.0 (66.65\% sand, $24.26 \%$ clay and $9.09 \%$ silt with fertility level of $180.8 \mathrm{~kg} \mathrm{~N} \mathrm{ha}^{-1}$, $16.0 \mathrm{~kg} \mathrm{P} \mathrm{ha}^{-1}$ and $165.0 \mathrm{~kg} \mathrm{~K} \mathrm{ha}^{-1}$ ). The leaf samples for scanning electron microscopy were prepared according to the method of Bozzola and Russell (1992). The tenth leaf from the first fully opened top leaf of the longest branch of each genotype was cut into $3 \mathrm{~mm}^{2}$ pieces and subsequently fixed in $2.5 \%$ glutaraldehyde (prepared in $0.2 \mathrm{M}$ sodium cacodylate buffer, $\mathrm{pH} 7.2$ ) for $2 \mathrm{~h}$. The samples were then postfixed for $3 \mathrm{~h}$ in $2 \%$ osmium tetroxide and dehydrated in an alcohol-acetone series at room temperature of $25 \pm 2{ }^{\circ} \mathrm{C}$. The dehydrated materials were then dried in a critical point drier (EMS-850, Electron Microscopy Sciences, Hatfield, Pennsylvania, USA) using $\mathrm{CO}_{2}$ as the transition fluid. The dried samples were mounted on the copper stubs, keeping the abaxial leaf surface up by using double-sided sticky tape, and then coated with gold (20 nm thickness) in a sputter coater (EMS-550, Electron Microscopy Sciences, Hatfield, Pennsylvania, USA). The coated samples were examined under scanning electron microscope (JEOL 100 CX II-ASID 4D, Tokyo, Japan) at $20 \mathrm{kV}$. The leaf surface features viz. stomatal size and their frequency, length of trichomes and idioblasts were measured in 25 fields of each 10 different leaf samples from different plants in each genotype. The leaf yield data were also recorded during spring season (main silkworm rearing season during March-April contributing $90 \%$ of the total silk production in sub tropics) from the sample of 96 plants at $0.9 \times 0.9 \mathrm{~m}$ spacing in between plants and rows in a plot area of $94.77 \mathrm{~m}^{2}$ replicated three times in randomized block design (total area $284.31 \mathrm{~m}^{2}$ ) and calculated for 1 ha in each genotype. Data collected for $3 \mathrm{yr}$ were averaged. All data were calculated for means and standard error.

\section{RESULTS AND DISCUSSION}

The pedigree and leaf yield of 16 mulberry genotypes, namely, 'S-30' (Vishala), 'S-1635', 'S-146', 'Anantha', 'Mandalaya', 'C-1730', 'C-2016', 'C-2017', 'RFS-175', 'Tr-10', 'V-1', 'S-41', 'K-2', 'Chinese White', 'BC ${ }^{-}$ 59' and 'Sujanpur Local' grown in Indian sub tropics are presented in Table 1 . The mulberry genotype S-30 (Vishala) revealed highest leaf yield of $7373.80 \mathrm{~kg} \mathrm{ha}^{-1}$ season $^{-1}$ followed by $6764.34 \mathrm{~kg} \mathrm{ha}{ }^{-1}$ season $^{-1}$ in ' $\mathrm{S}$ 1635 '. The lowest leaf yield (3249.38 $\mathrm{kg} \mathrm{ha}^{-1}$ season $\left.^{-1}\right)$ was recorded in the genotype 'Sujanpur Local' followed by ' $\mathrm{BC}_{2}-59$ ' ( $4038.27 \mathrm{~kg} \mathrm{ha}^{-1}$ season $\left.^{-1}\right)$. When mulberry genotypes were categorized on the basis of range in leaf yield, the genotypes 'C-1730', 'Mandalaya', 'Anantha', 'S-146', 'S-1635' and 'S-30' (Vishala) were found with higher leaf yield, more than $6000 \mathrm{~kg} \mathrm{ha}^{-1}$ season $^{-1}$ 
Table 1. Pedigree and leaf yield potential of different mulberry genotypes under sub tropics.

\begin{tabular}{|c|c|c|c|}
\hline $\begin{array}{l}\text { Mulberry } \\
\text { genotype }\end{array}$ & Origin & Pedigree & $\begin{array}{l}\text { Leaf yield } \\
\text { per season }\end{array}$ \\
\hline & & & $\mathrm{kg} \mathrm{ha}^{-1}$ \\
\hline S-30 (Vishala) & $\begin{array}{l}\text { Indigenous } \\
\text { (Mysore, India) }\end{array}$ & Natural selection & 7373.80 \\
\hline S-1635 & $\begin{array}{l}\text { Indigenous } \\
\text { (Berhampore, India) }\end{array}$ & $\begin{array}{l}\text { Selection from seedlings of open pollinated seeds } \\
\text { collected from mother plant CSRS } 1\end{array}$ & 6764.34 \\
\hline S-146 & $\begin{array}{l}\text { Indigenous } \\
\text { (Berhampore, India) }\end{array}$ & Open pollinated hybrid selection & 6476.54 \\
\hline Anantha & $\begin{array}{l}\text { Indigenous } \\
\text { (Ananthpur, India) }\end{array}$ & $\begin{array}{l}\text { Selection from the population of mulberry var. RFS- } \\
135\end{array}$ & 6352.31 \\
\hline Mandalaya & $\begin{array}{l}\text { Indigenous } \\
\text { (Berhampore, India) }\end{array}$ & Clonal selection & 6211.31 \\
\hline C-1730 & $\begin{array}{l}\text { Indigenous } \\
\text { (Berhampore, India) }\end{array}$ & $\begin{array}{l}\text { Triploid cross } \mathrm{T}_{25} \text { tetraploid mother and S-162 diploid } \\
\text { male parent }\end{array}$ & 6121.31 \\
\hline C-2016 & $\begin{array}{l}\text { Indigenous } \\
\text { (Berhampore, India) }\end{array}$ & Open pollinated hybrid selection & 5954.94 \\
\hline C-2017 & $\begin{array}{l}\text { Indigenous } \\
\text { (Berhampore, India) }\end{array}$ & Open pollinated hybrid selection & 5736.27 \\
\hline RFS-175 & $\begin{array}{l}\text { Indigenous } \\
\text { (Mysore, India) }\end{array}$ & Open pollinated hybrid selection & 5722.88 \\
\hline $\operatorname{Tr}-10$ & $\begin{array}{l}\text { Indigenous } \\
\text { (Berhampore, India) }\end{array}$ & $\begin{array}{l}\text { Cross between colchicine induced tetraploid of (Morus } \\
\text { indica x S-1) x Philippine }(2 x)\end{array}$ & 5681.48 \\
\hline V-1 & $\begin{array}{l}\text { Indigenous } \\
\text { (Mysore, India) }\end{array}$ & $\begin{array}{l}\text { Hybrid of mulberry genotypes S-30 x Berhampore } \\
\text { C776 }\end{array}$ & 5516.42 \\
\hline S-41 & $\begin{array}{l}\text { Indigenous } \\
\text { (Mysore, India) }\end{array}$ & Ethyl methane sulfate (EMS) seed mutant & 5241.47 \\
\hline K-2 & $\begin{array}{l}\text { Indigenous } \\
\text { (Mysore, India) }\end{array}$ & Selection from the seedlings population & 5037.56 \\
\hline Chinese white & $\begin{array}{l}\text { Indigenous } \\
\text { (Pampore, India) }\end{array}$ & Clonal selection & 4659.87 \\
\hline $\mathrm{BC}_{2}-59$ & $\begin{array}{l}\text { Indigenous } \\
\text { (Berhampore, India) }\end{array}$ & $\begin{array}{l}\text { Back crossing of female plant }(M \text {. indica var. Matigari } \\
x \text { Kosen) and with recurrent parent Kosen }\end{array}$ & 4038.27 \\
\hline Sujanpur Local & $\begin{array}{l}\text { Indigenous } \\
\text { (Jammu, India) }\end{array}$ & Open pollinated hybrid selection & 3249.38 \\
\hline $\begin{array}{l}\text { Critical } \\
\text { Difference at } 5 \%\end{array}$ & & & 391.40 \\
\hline
\end{tabular}

under category I, while other genotypes ranked between categories II and III being the lowest leaf yield of 3249.38 $\mathrm{kg} \mathrm{ha}^{-1}$ season $^{-1}$ in Sujanpur Local (Table 2).

Likewise, all genotypes differed in the stomatal size (Figures 1 and 2), stomatal number per $1333.2 \mu \mathrm{m}^{2}$ area (Figures 3 and 4) and trichome and idioblast lengths (Table 3, Figures 5 to 6). Based on four categories of variation in stomatal size, a very small size of stomata (15.609 $\mu \mathrm{m})$ was observed in the genotype Sujanpur Local under category I. On the other side, the genotype $\mathrm{BC}_{2}-59$ was observed with exceptionally very large size of stomata $(99.638 \mu \mathrm{m})$ falling under category IV (Table 4). Similarly, stomatal number per $1333.2 \mu \mathrm{m}^{2}$ area varied between 8 and 16 . 
Table 2. Categories for variation in leaf yield potentiality of different mulberry genotypes in Indian sub tropics.

\begin{tabular}{lcl}
\hline Category & Range in leaf yield potentiality & \multicolumn{1}{c}{ Mulberry genotypes } \\
\hline I & $>6000 \mathrm{~kg} \mathrm{ha}^{-1}$ season $^{-1}$ & $\mathrm{C}-1730$, Mandalaya, Anantha, S-146, S-1635 and S-30 (Vishala) \\
II & $5000-6000 \mathrm{~kg} \mathrm{ha}^{-1}$ season $^{-1}$ & $\mathrm{~K}-2, \mathrm{~S}-41, \mathrm{~V}-1$, Tr-10, RFS-175, C-2016 and C- 2017 \\
III & $<5000 \mathrm{~kg} \mathrm{ha}^{-1}$ season $^{-1}$ & Chinese white, BC $2-59$ and Sujanpur Local \\
\hline
\end{tabular}

When categorized, the genotypes $\mathrm{BC}_{2}-59, \mathrm{C}-1730$, Mandalaya, Tr-10, C-2017, K-2 and Sujanpur Local were found with less than 10 stomata in $1333.2 \mu \mathrm{m}^{2}$ area falling under category I (Table 5). However, the genotypes RFS-175, Anantha, V-1, S-30 (Vishala) and S-41 were recorded with more than 15 stomata falling under category III. The genotype $\mathrm{BC}_{2}-59$, which revealed largest stomatal size had less than 10 stomata per unit of area. Most of the genotypes viz. S-41, K-2, Tr-10, C-2017, S-30 (Vishala), Mandalaya, V-1, Chinese white and C-2016 ranged under the category II of size 25$50 \mu \mathrm{m}$. In this regard, Susheelamma and Datta (1993)
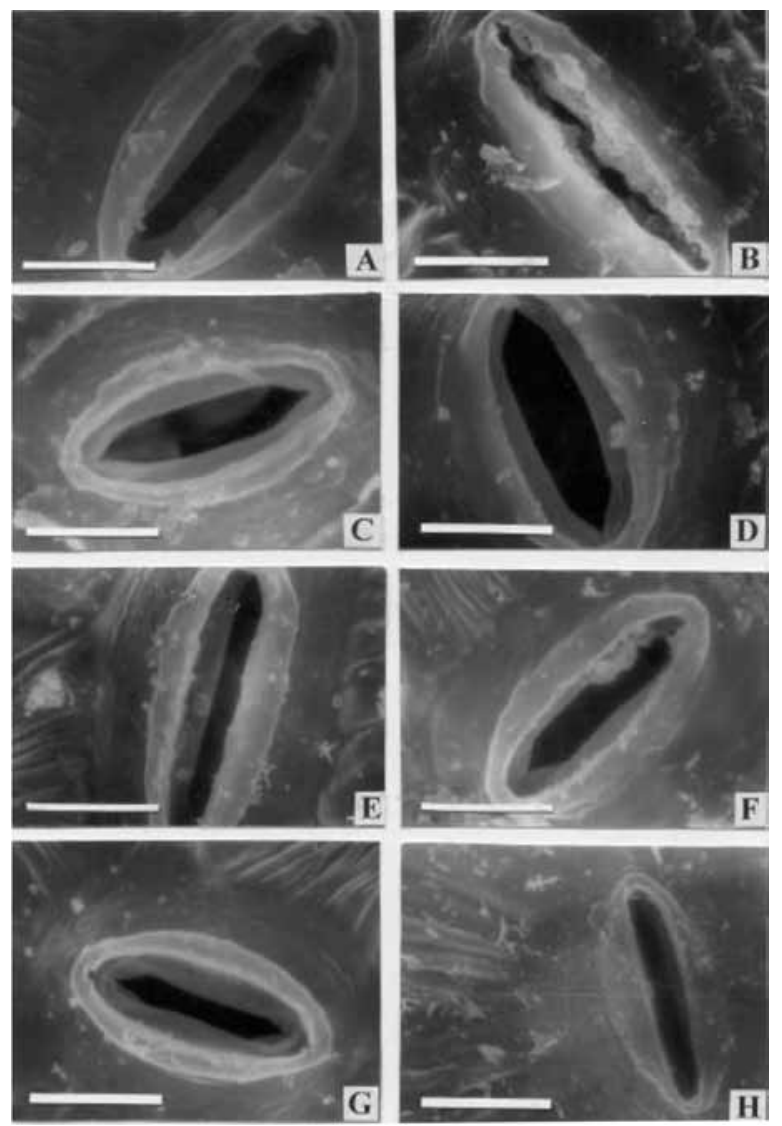

Figure. 1. Stomatal size in mulberry genotype $\mathrm{BC}_{2}-59$ (A), S-1635 (B), RFS-175 (C), C-1730 (D), S-146 (E), Anantha (F), C-2016 (G), Chinese white (H). Scale bar $=5 \mu \mathrm{m}$. Magnification $=4000 \mathrm{X}$. have correlated small stomatal size with leaf moisture retention capacity maintaining high plant water potential in mulberry. It is therefore the reason for very poor leaf yield of $\mathrm{BC}_{2}-59\left(4038.270 \mathrm{~kg} \mathrm{ha}^{-1}\right.$ season $\left.^{-1}\right)$, as maximum water might be transpiring through very large stomata. In Indian sub tropics, where mulberry is cultivated only under rainfed conditions, the genotype may not be of much use for cultivation practices being poor leaf yielder with undesirable leaf surface characteristics.

The present study also revealed a wide variation in trichome and idioblast lengths in all the genotypes. The trichomes were found glandular and idioblasts were
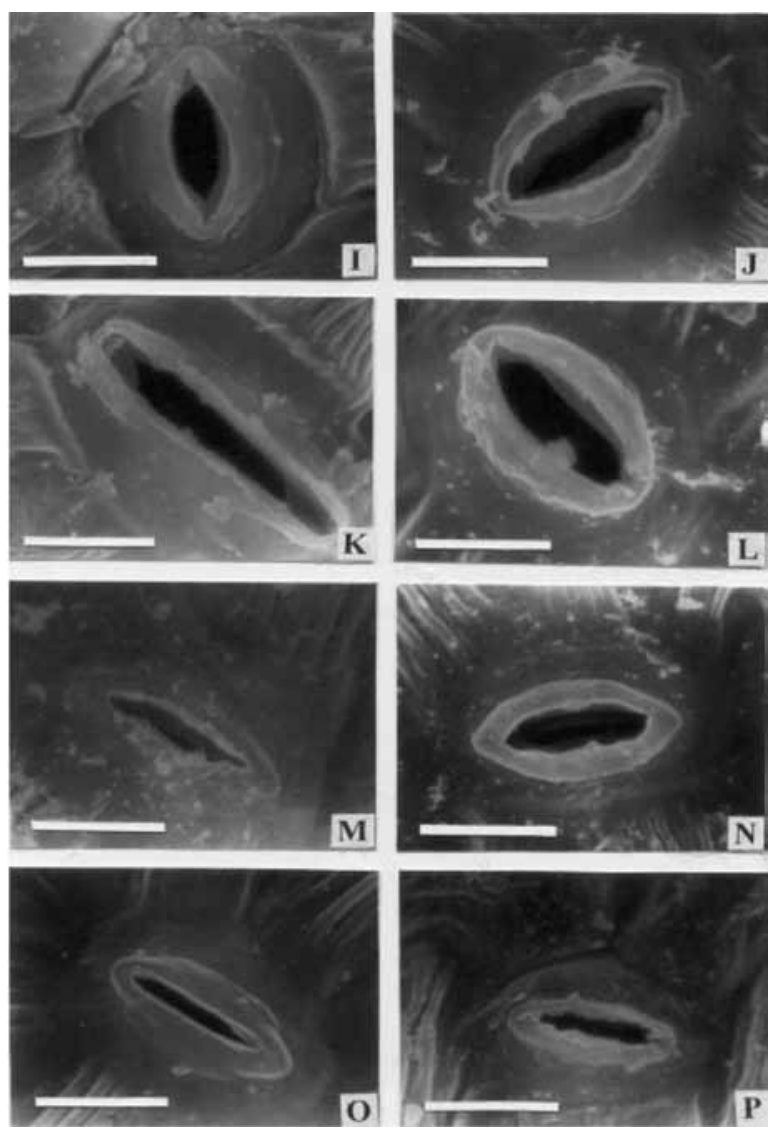

Figure 2. Stomatal size in mulberry genotype V-1 (I), Mandalaya (J), S-30 (Vishala) (K), C-2017 (L), Tr-10 (M), K-2 (N), S-41 (O) and Sujanpur Local (P). Scale bar $=5 \mu \mathrm{m}$. Magnification $=4000 X$. 

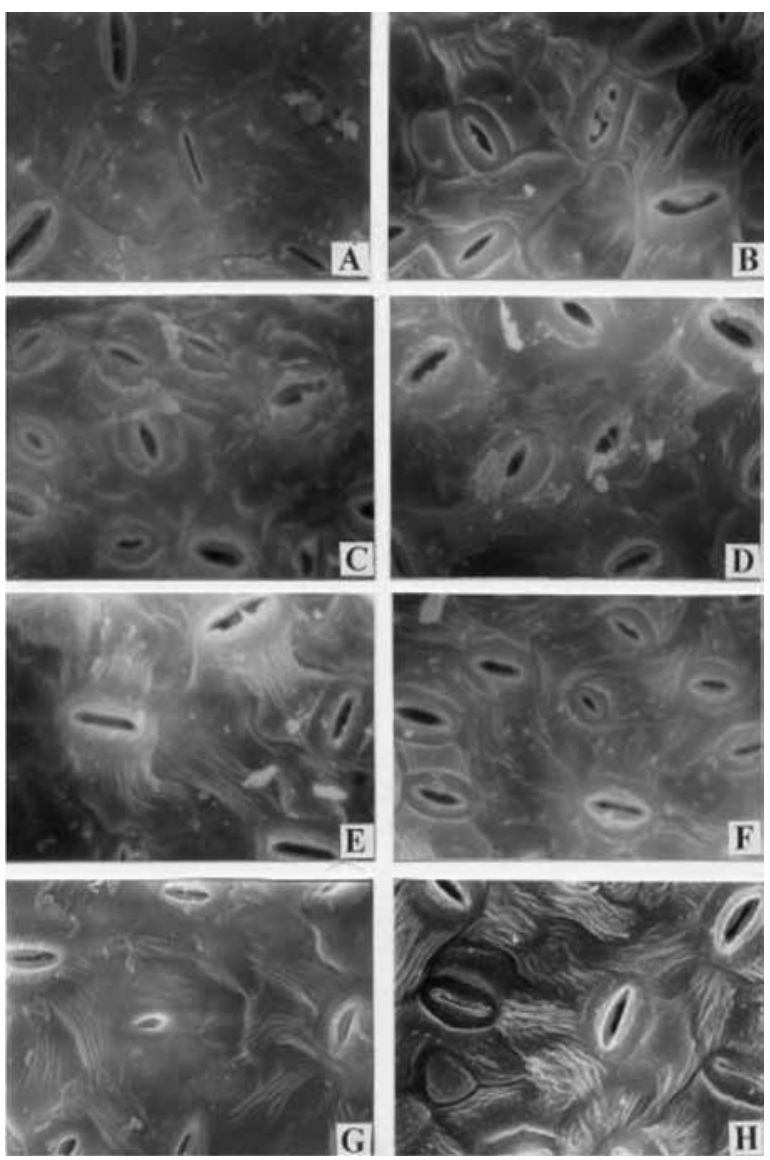

Figure 3. Number of stomata per $1333.2 \mu \mathrm{m}^{2}$ area in mulberry genotype $\mathrm{BC}_{2}-59$ (A), S-1635 (B), RFS-175 (C), C-1730 (D), S-146 (E), Anantha (F), C-2016 (G), Chinese white $(\mathrm{H})$. Magnification $=1500 \mathrm{X}$.

long or short notched, with hemispherical shape, having microtubercules all around their surface. The genotypes S-146, Mandalaya, K-2, S-41 and Sujanpur Local had short trichomes as well as idioblasts (Tables 6 and 7) falling under the category I. The genotype S-30 (Vishala) was observed with longest trichomes as well as idioblasts falling under the category III. It clearly indicates that though this genotype had highest leaf production, may have poor acceptability to the silkworms in accordance with Kesavacharyulu et al. (2004). As is the complex situation in sericulture, leaf acceptability to the silkworms is more important than any other parameter. Further, the genotypes $\mathrm{BC}_{2}-59, \mathrm{~V}-1$ and RFS-175 may not be desirable for Indian sub tropics because of poor leaf yield and leaf surface characteristics having long trichomes and idioblasts. Among all genotypes, Mandalaya seems
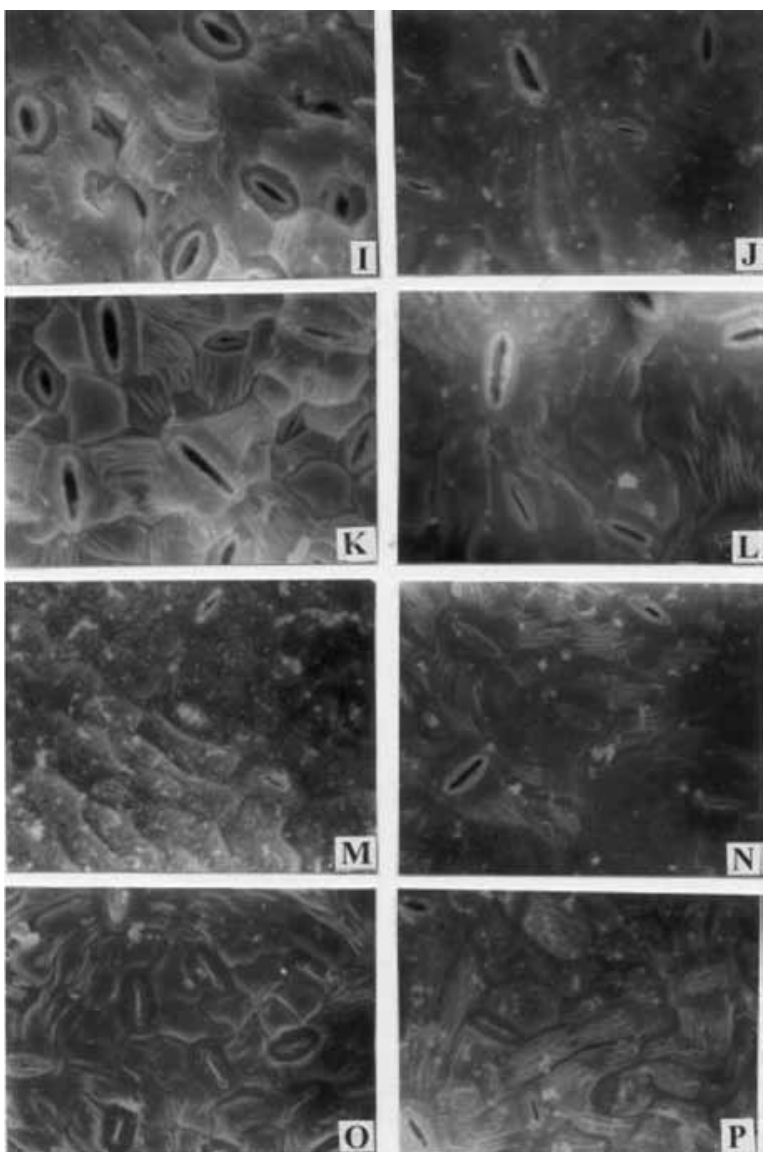

Figure 4. Number of stomata per $1333.2 \mu \mathrm{m}^{2}$ area in mulberry genotype V-1 (I), Mandalaya (J), S-30 (Vishala) (K), C-2017 (L), Tr-10 (M), K-2 (N), S-41 (O) and Sujanpur Local $(\mathrm{P})$. Magnification $=1500 \mathrm{X}$.

to be very promising having higher leaf yield with small stomatal size, less number of stomata per unit of area and shorter trichome and idioblast lengths.

\section{CONCLUSIONS}

The present study suggests Mandalaya as the most promising mulberry genotype with higher leaf yield and shorter trichome and idioblast lengths for silkworm rearing in addition to the only ruling genotype S-146 presently used under sub tropical conditions. The study reveals that the mulberry genotypes S-146, Mandalaya, K-2, S-41 and Sujanpur Local can be exploited for mulberry improvement programs considering favorable leaf surface characteristics in Indian sub tropics. 
Table 3. Variation in stomatal size and their frequency and trichomes and idioblasts length in different mulberry genotypes of Indian sub tropics.

\begin{tabular}{|c|c|c|c|c|}
\hline $\begin{array}{l}\text { Mulberry } \\
\text { genotypes }\end{array}$ & $\begin{array}{l}\text { Stomatal size } \\
\quad(L \times W)\end{array}$ & $\begin{array}{l}\text { Stomatal number per } \\
1333.2 \mu \mathrm{m}^{2} \text { area }\end{array}$ & $\begin{array}{l}\text { Trichomes } \\
\text { length }\end{array}$ & $\begin{array}{l}\text { Idioblasts } \\
\text { length }\end{array}$ \\
\hline & $-\mu \mathrm{m}-$ & & 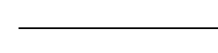 & 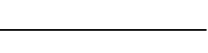 \\
\hline $\mathrm{BC}_{2}-59$ & $99.638 \pm 0.085$ & $08.001 \pm 0.024$ & $29.124 \pm 0.193$ & $17.997 \pm 0.126$ \\
\hline S-1635 & $61.829 \pm 0.103$ & $11.017 \pm 0.015$ & $24.207 \pm 0.088$ & $24.783 \pm 0.133$ \\
\hline RFS-175 & $60.414 \pm 0.110$ & $15.116 \pm 0.042$ & $21.142 \pm 0.081$ & $24.314 \pm 0.248$ \\
\hline S-146 & $57.573 \pm 0.091$ & $11.131 \pm 0.017$ & $18.958 \pm 0.104$ & $11.704 \pm 0.249$ \\
\hline C-1730 & $56.476 \pm 0.094$ & $08.023 \pm 0.027$ & $21.141 \pm 0.055$ & $22.056 \pm 0.077$ \\
\hline Anantha & $51.367 \pm 0.103$ & $15.017 \pm 0.044$ & $22.315 \pm 0.078$ & $14.018 \pm 0.157$ \\
\hline C-2016 & $47.638 \pm 0.123$ & $10.288 \pm 0.017$ & $19.147 \pm 0.075$ & $18.401 \pm 0.078$ \\
\hline Chinese white & $47.542 \pm 0.146$ & $11.996 \pm 0.034$ & $20.075 \pm 0.217$ & $11.995 \pm 0.163$ \\
\hline $\mathrm{V}-1$ & $47.211 \pm 0.089$ & $15.101 \pm 0.045$ & $21.101 \pm 0.088$ & $15.120 \pm 0.238$ \\
\hline Mandalaya & $46.623 \pm 0.115$ & $08.025 \pm 0.166$ & $17.074 \pm 0.148$ & $13.997 \pm 0.052$ \\
\hline S-30 (Vishala) & $46.276 \pm 0.082$ & $16.101 \pm 0.050$ & $25.781 \pm 0.178$ & $30.118 \pm 0.088$ \\
\hline C-2017 & $40.103 \pm 0.133$ & $09.344 \pm 0.087$ & $22.085 \pm 0.166$ & $14.034 \pm 0.105$ \\
\hline $\operatorname{Tr}-10$ & $36.968 \pm 0.079$ & $08.125 \pm 0.019$ & $22.926 \pm 0.189$ & $21.005 \pm 0.164$ \\
\hline $\mathrm{K}-2$ & $31.924 \pm 0.116$ & $09.212 \pm 0.007$ & $19.077 \pm 0.165$ & $14.005 \pm 0.163$ \\
\hline S-41 & $28.489 \pm 0.124$ & $15.012 \pm 0.088$ & $16.974 \pm 0.023$ & $12.011 \pm 0.141$ \\
\hline Sujanpur Local & $15.609 \pm 0.088$ & $08.005 \pm 0.073$ & $16.351 \pm 0.164$ & $11.712 \pm 0.116$ \\
\hline
\end{tabular}
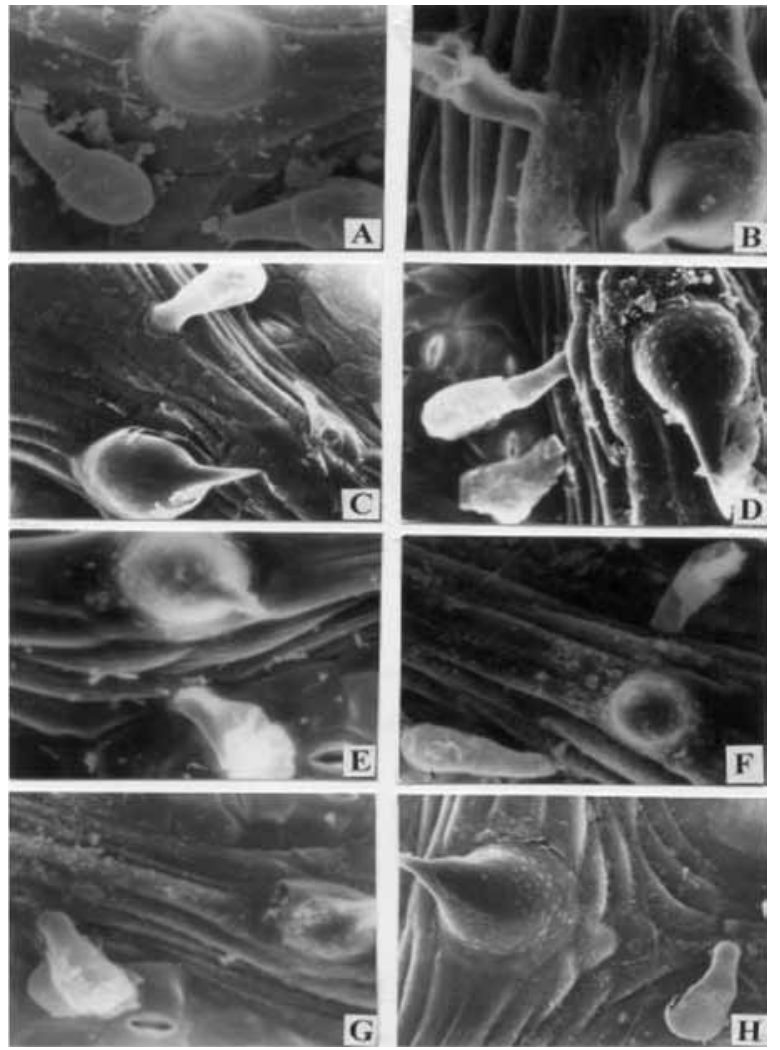

Figure 5. Trichomes and idioblasts in mulberry genotype $\mathrm{BC}_{2}-59$ (A), S-1635 (B), RFS-175 (C), C-1730 (D), S-146 (E), Anantha (F), C-2016 (G), Chinese white (H). Magnification $=1000 \mathrm{X}$.
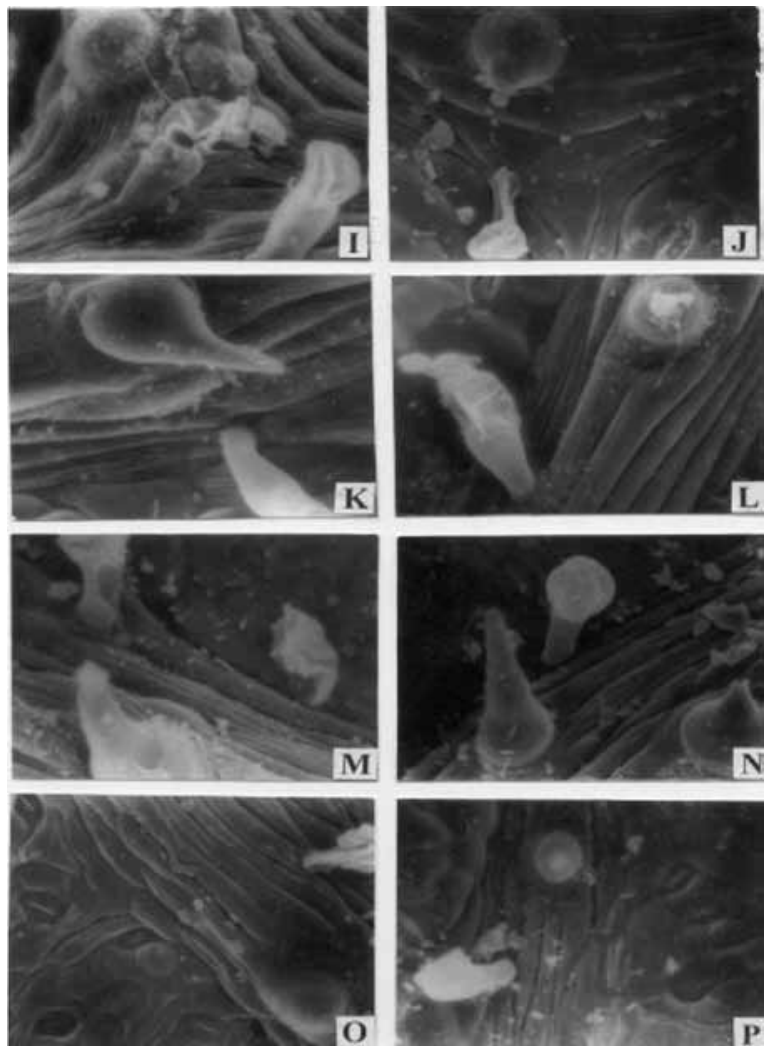

Figure 6. Trichomes and idioblasts in mulberry genotype V-1 (I), Mandalaya (J), S-30 (Vishala) (K), C-2017 (L), Tr-10 (M), K-2 (N), S-41 (O), and Sujanpur Local (P). Magnification $=1000 \mathrm{X}$. 
Table 4. Different categories for variation in stomatal size of different mulberry genotypes in Indian sub tropics.

\begin{tabular}{lcl}
\hline Category & Range of stomatal size $(\mathbf{L} \mathbf{x}$ W) & \multicolumn{1}{c}{ Mulberry genotypes } \\
\hline I & Very small size $(<25 \mu \mathrm{m})$ & Sujanpur Local \\
II & Small size $(25-50 \mu \mathrm{m})$ & S-41, K-2, Tr-10, C-2017, S-30 (Vishala), Mandalaya, V-1, \\
& & Chinese white, and C-2016 \\
III & Medium size $(50-75 \mu \mathrm{m})$ & Anantha, C-1730, S-146, RFS-175, and S-1635 \\
IV & Large size $(>75 \mu \mathrm{m})$ & $\mathrm{BC}_{2}-59$ \\
\end{tabular}

Table 5. Different categories for variation in stomatal number per $1333.2 \mu \mathrm{m}^{2}$ area of different mulberry genotypes in Indian sub tropics.

\begin{tabular}{lcl}
\hline Category & Range of stomatal number & \multicolumn{1}{c}{ Mulberry genotypes } \\
\hline I & Low $(<10)$ & $\mathrm{BC}_{2}-59, \mathrm{C}-1730$, Mandalaya, Tr-10, C-2017, K-2, and Sujanpur \\
& & Local \\
II & Medium $(10-15)$ & S-1635, S-146, C-2016, and Chinese white \\
III & High $(>15)$ & RFS-175, Anantha, V-1, S-30 (Vishala), and S-41 \\
\hline
\end{tabular}

Table 6. Different categories for variation in trichome length of different mulberry genotypes in Indian sub tropics.

\begin{tabular}{lll}
\hline Category & Range of trichome length & \multicolumn{1}{c}{ Mulberry genotypes } \\
\hline I & Short $(<20 \mu \mathrm{m})$ & S-146, C-2016, Mandalaya, K-2, S-41, and Sujanpur Local \\
II & Medium $(20-25 \mu \mathrm{m})$ & S-1635, RFS-175, C-1730, Anantha, Chinese white, V-1, \\
& & C-2017, and Tr-10 \\
III & Long $(>25.00 \mu \mathrm{m})$ & $\mathrm{BC}_{2}-59$ and S-30 (Vishala) \\
\hline
\end{tabular}

Table 7. Different categories for variation in idioblast length of different mulberry genotypes in Indian sub tropics.

\begin{tabular}{lll}
\hline Category & Range of idioblasts length & \multicolumn{1}{c}{ Mulberry genotypes } \\
\hline I & Short $(<15 \mu \mathrm{m})$ & $\begin{array}{l}\text { S-146, Anantha, Chinese white, Mandalaya, C-2017, K-2, S-41, } \\
\text { and Sujanpur Local }\end{array}$ \\
II & Medium $(15-25 \mu \mathrm{m})$ & $\mathrm{BC}_{2}-59, \mathrm{C}-1635$, RFS-175, C-1730, C-2016, V-1, and Tr-10 \\
III & Long $(>25 \mu \mathrm{m})$ & $\mathrm{S}-30$ (Vishala) \\
\hline
\end{tabular}

\section{RESUMEN}

Microscopía electrónica de barrido de la superficie foliar de 16 genotipos de Morus spp. en relación a su valor alimenticio para crianza del gusano de la seda (Bombyx mori L.). La morera (Morus spp.) es la única planta de alimento para el gusano de la seda (Bombyx mori L.). En los sub-trópicos de la India, 'S-146' es el único genotipo popular y predominante de morera para criarlo. Como resultado, la disponibilidad de hojas es siempre el factor limitante y, por lo tanto, los subtrópicos contribuyen con menos de $1 \%$ del total de la producción nacional de seda comparado con más de $60 \%$ bajo condiciones tropicales. Además de las condiciones climáticas, esto se debe al número muy limitado de genotipos de morera disponible en esta región para la crianza de gusanos de seda. Se introdujeron 15 genotipos de morera (Tr-10', 'Chinese White', 'K-2', 'Sujanpur Local', 'BC ${ }_{2}-59$ ', 'S-1635', 'C-1730', 'Mandalaya', 'S30' (Vishala), 'RFS-175', 'Anantha', 'C-2016', 'C-2017', 'S-41' and ' $\mathrm{V}-1$ ') a los sub-trópicos, pero permanecieron inexplorados. En sericultura, la superficie foliar es también un parámetro importante para la aceptación por parte del gusano por no tener inconvenientes alimentarios y para los programas de mejoramiento de morera. El objetivo del estudio fue explorar las posibilidades de utilizar estos 16 
genotipos para sericultura evaluando las características de su superficie foliar por microscopía electrónica de barrido. Los genotipos se agruparon en diferentes categorías según producción foliar, tamaño y número de estomas por unidad de área, y longitud de tricomas e idioblastos. Destacó 'Mandalaya' junto al popular 'S-146' por su producción foliar y características deseadas de superficie foliar. Además, basado en las características de sus hojas, los genotipos 'K-2', 'S-41' y 'Sujanpur Local' también se sugieren para desarrollar genotipos de morera de alto rendimiento en los sub-trópicos de la India.

Palabras clave: Morus indica L., microscopía electrónica de barrido, estomas, tricomas, idioblastos, producción foliar, sericultura.

\section{LITERATURE CITED}

Biasiolo, M., M.T. Canal, and N. Tomadore. 2004. Micromorphological characterization of ten mulberry cultivars (Morus spp.). Econ. Bot. 58:639-646.

Bozzola, J.J., and L.D. Russell. 1992. Electron microscopy - Principles and techniques for biologists. p. 41-63. Jones \& Bartlett Publishers, Boston, Massachusetts, USA.

Fujita,H., and C. Uchikawa. 1986. Electron microscopical study of mulberry with special reference to the identification of cultivars. In Kitaura, K., T. Akihama, H. Kakaimura, K. Nakajima, M. Horie, and I. Kozaki (eds.) Development of new technology for identification of tree crops and ornamentals. Ministry of Agriculture, Forestry and Fisheries (MAFF), Tokyo, Japan.

Katsumata, F. 1972. Relationship between the length of styles and the shape of idioblasts in mulberry leaves with special reference to the classification of mulberry trees. J. Sericult. Sci. Japan 41:387-395.

Kesavacharyulu, K., V. Kumar, and A. Sarkar. 2004. Scanning electron microscopic studies on leaf surface trichomes in mulberry and its influence on rearing performance of silkworm, Bombyx mori L. Int. J. Ind. Entomol. 8:33-41.
Levin, D.A. 1973. The role of trichomes in plant defense. Q. Rev. Biol. 48:3-15.

Melikyan, N.M., and S.S. Babyan. 1971. Anatomical characteristics of the leaves of some mulberry genotypes in relation to their feeding value. Biologicheskii Zhurnal Armanii. 24:50-56.

Peter, A.J., T.G. Shanower, and J. Romeis. 1995. The role of plant trichomes in insect resistance: A selective review. Phytophaga 7:41-63.

Shah, A.M., and P. Kachroo. 1975. Comparative anatomy in cuticles (1) the trichomes in moraceae. J. Ind. Bot. Soc. 54:138-153.

Singh, B.B., H.H. Hardley, and R.L. Bernard. 1971. Morphology of pubescence in soybeans and its relationship to plant vigour. Crop Sci. 11:13-16.

Singhal, B.K., A. Dhar, and M.A. Khan. 2006. Leaf quality of Mulberry (Morus sp.) under varying cultural practices in Indian sub tropics. p. 54-59. Proceedings of Regional Seminar on Prospect \& Problems of Sericulture as an Economic Enterprise in North West India, Dehradun, Uttarakhand, India. 1112 November.

Singhal, B.K., A. Dhar, S.M.H. Qadri, and M.M. Ahsan. 2001. Mulberry nutrition for development of sericulture in Jammu \& Kashmir. Asian Textile J. $10: 35-42$.

Singhal, B.K., V. Kumar, and M.V. Rajan. 1999. SEM studies on the leaf surface of promising mulberry (Morus spp.) genotypes. J. Plant Biol. 42:71-74.

Southwood, R. 1986. Plant surfaces and insects- an overview. p. 1-22. In Juniper, B.E., T. Southwood (eds.) Insects and plant surface. Edward Arhold Publishers Ltd., London, UK.

Susheelamma, B.N., and R.K. Datta. 1993. Breeding for stress resistance in mulberry. p. 889-903. Proc. Int. Golden Jubilee Symp. on Genetic Research and Education. 2. Current trends and next 50 years. Indian Agricultural Research Institute (IARI), New Delhi, India.

Susheelamma, B.N., and M.S. Jolly. 1986. Evaluation of morpho-physiological parameters associated with drought resistance in mulberry. Indian J. Seric. 25:6-14. 